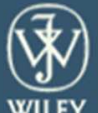

BioEssays

WILEY

\title{
The many roles of type II phosphatidylinositol 4-kinases in membrane trafficking: New tricks for old dogs
}

\begin{tabular}{|r|l|}
\hline Journal: & BioEssays \\
\hline Manuscript ID & bies.201700145.R2 \\
\hline Wiley - Manuscript type: & Review essay \\
\hline Date Submitted by the Author: & n/a \\
\hline Keywords: & $\begin{array}{l}\text { phosphatidylinositol 4-kinase, membrane trafficking, trans-Golgi network, } \\
\text { endosome, sorting }\end{array}$ \\
\hline Scientific Area: & Cell biology, membrane trafficking \\
\hline &
\end{tabular}

SCHOLARONE ${ }^{m}$

Manuscripts 
The many roles of type II phosphatidylinositol 4-kinases in membrane trafficking: New tricks for old dogs

Shane Minogue*

*Lipid and Membrane Biology Group,

UCL Division of Medicine,

Royal Free Campus,

University College London,

Rowland Hill Street,

London,

NW3 2PF,

UK.

Tel: +44-20-7433-2875; fax: +44-20-7433-2817; e-mail: s.minogue@ucl.ac.uk

Keywords: phosphatidylinositol 4-kinase, membrane trafficking, TGN, endosome, sorting.

Abbreviations: Apg, autophagosome; EE, early endosome; LE, late endosome;

Lys, lysosome; Pg, phagosome; RE, recycling endosome; SE, sorting endosome;

TGN, trans-Golgi network.

Bioessays rubric: Review Essay. 


\section{Summary}

The type II phosphatidylinositol 4-kinases (PI4KIIs) produce the lipid phosphatidylinositol 4-phosphate (Ptdlns4P) and participate in a confusing variety of membrane trafficking and signalling roles. This review argues that both historical and contemporary evidence supports the function of the PI4KIIs in numerous trafficking pathways, and that the key to understanding the enzymatic regulation is through membrane interaction and the intrinsic membrane environment.

By summarising new research and examining the trafficking roles of the PI4KIls in the context of recently solved molecular structures, I highlight how mechanisms of PI4KII function and regulation are providing insights into the development of cancer and in neurological disease. I present an integrated view connecting the cell biology, molecular regulation and roles in whole animal systems of these increasingly important proteins. 


\section{Introduction}

The phosphatidylinositol 4-kinases (PI4Ks) occupy a central position in phosphatidylinositol (Ptdlns) metabolism because they catalyse the first step in the biosynthesis of four of the seven phosphoinositide (PI) lipids ${ }_{2}{ }^{[1]}$ all of which are intimately involved in membrane trafficking ${ }_{-}^{[2,3]}$ Their primary enzymatic product, phosphatidylinositol 4-phosphate (Ptdlns4P), is a signalling precursor and an important regulator of membrane traffic ${ }^{[3]}$ that can be produced by either of the four PI4K activities. The extensively studied type III PI4Ks (PI4KIII $\alpha$ and PI4KIII $\beta$ ) were the first PI4K enzymes to be identified at the molecular level and these isoforms produce Ptdlns4P at the plasma membrane (PM) and Golgi, respectively (reviewed in depth elsewhere ${ }^{[4,5]}$ ). The type II PI4KIIs (PI4KII $\alpha$ and PI4KII $\beta$ ) were identified more recently ${ }^{[6,7]}$ and we are only now beginning to understand in detail how they influence membrane identity and trafficking.

PI4KII was first described decades ago as a membrane-bound enzyme activated by non-ionic detergents and inhibited by adenosine ${ }_{-}^{[6,7]}$ For many years, interest in PI4K activities was driven by their requirement in $\operatorname{Ptdlns}(4,5) P_{2^{-}}$ dependent signalling at the plasma membrane. However, recent years have seen profound advances in our understanding of PI4KII in membrane trafficking that have largely eclipsed the role of PI4KII in signalling. The functions of Ptdlns $4 P$ have also expanded into a much broader subcellular distribution than previously envisaged. Discrete pools of Ptdlns4P outside of the Golgi are now recognised on early (EE) and sorting endosomes (SEs), late endosomes (LEs), at the plasma membrane $(P M)^{[8-10]}$ and even on different subdomains of the trans-Golgi network (TGN)-endosomal system ${ }^{[11]}$ (Figure 2). The PI4KIl $\alpha$ and PI4KII $\beta$ enzymes have also been detected at the PM and in endosomal compartments containing Ptdlns4P. Subcellular distribution of both PI4KII isoforms and the Pls they produce is therefore broad and overlapping, leading to questions of whether the enzymes have redundant functions.

We now have much information relating to the trafficking events controlled by these enzymes and the Ptdlns4P they synthesise. The recently solved structures of the PI4KII isoforms place their hitherto mysterious properties into a molecular framework, thereby allowing us to rationalise their functions and explain the unique biochemistry of these two key PI kinases. This review discusses the 
structure and function of the PI4KIIs, the differences and similarities in their regulation and their involvement in physiological processes and disease.

\section{The PI4KIIs are an ancient kinase family}

The PI4KII family eluded molecular identification for many years because their gene sequences differed from those of known PI kinases ${ }_{-}^{[12,13]}$ Discovery of the alpha isoform (PI4KII $\alpha$ ) revealed an unexpected second isoform that we termed PI4KII $\beta_{-}^{[13]}$ The PI4KIIs are distinct from the PI4KIII family whose members are clearly homologous to the archetypal protein kinase PKA and the PI3Ks, thereby placing the PI4KII structures unequivocally within the PI3K/protein kinase superfamily. ${ }_{-}^{[5]}$

Three-dimensional structures of recombinant human PI4KIl $\alpha$ have been reported recently ${ }^{[14,15]}$ and the data subjected to extensive molecular modelling to predict biochemical behaviour of the proteins. These studies illustrate how the enzymes differ from the phosphoinositide 3-kinase (PI3K) superfamily and how the PI4KIls interact with membranes. The structures also offer explanations for several unique biochemical properties of the PI4KIIs such as sensitivity to detergent, cholesterol and adenosine that were first described during the characterisation of purified PI4KII activity. The models also provide valuable insights into the regulation of PI4KII activity.

PI4KIl $\alpha$ has a flattened interface that contacts membranes, similar to features reported for the PI3Ks and phosphatidylinositol 4-phosphate 5-kinases (PIP5Ks $)_{2}^{[16]}$ suggesting that these evolutionarily distant proteins have retained a structural characteristic determining membrane interaction. Overall the catalytic domain of PI4KIla is similar to PI3Ks in that it is composed of $\mathrm{N}$ - and C-terminal lobes (Figure 1A) but with additional insertions not found in PI3Ks. A search for related structures showed that the closest relatives of PI4KIl $\alpha$ are protein kinases such as the Helicobacter pylori pro-inflammatory kinase CTKA, thus indicating an ancient evolutionary relationship with the protein Ser/Thr kinases.

PI4KIl $\alpha$ has a nucleotide-binding pocket distinct from those found in PI3Ks, which accounts for its insensitivity to PI3K inhibitors such as wortmannin. Another feature significantly different from the PI3Ks is a glycine-rich loop (G-loop) ${ }^{[14]}$ that is likely to determine nucleotide-binding specificity and is potentially responsible for 
the sensitivity of PI4KII $\alpha$ to adenosine. Co-crystallisation of PI4KIl $\alpha$ in the presence of ADP indicates that the ATP binding pocket is positioned so that the terminal $\gamma$ phosphate is oriented in direct apposition to the membrane, where its PI substrate resides $_{\underline{-}}{ }^{[15]}$

Numerous parts of the PI4KII $\alpha$ molecule interact with membranes but multiple palmitoylation performs a special role by bringing a nearby amphipathic helix and the catalytic core close to the membrane (Figure 1B). This causes the nucleotide-binding G-loop, a putative kinase activation loop, to interact with membranes along with elements that form the PI binding pocket. ${ }_{-}^{[14]}$ Together, these elements stabilise critical regions of the active site leading to a more robust kinase activity. This tight interaction with the membrane and the effect of membrane association on activity, may explain why PI4KIl $\alpha$ is regulated mainly by membrane composition and the availability of Ptdlns substrate. ${ }_{-}^{[17]} A$ second hydrophobic pocket has been identified in the C-terminal lobe of PI4KII ${ }^{[15]}$ and, although the physiological ligand that binds this is unknown, candidates include cholesterol, an important membrane organiser and $\mathrm{PI} 4 \mathrm{KIl} \alpha$ regulator.

The N-termini of the PI4KIls lack primary sequence homology, but contain protein binding sites that determine isoform-specific functions (Figure 1A). Historically, the two PI4KII activities could not be distinguished in cell and tissue extracts and, unsurprisingly, the structure of the conserved core of PI4KII $\beta$ is very similar to that of PI4KII $\alpha_{\underline{a}}^{[18]}$ Recently an isoform-selective small molecule inhibitor, $\mathrm{PI}-273$, has been developed that is approximately 30 times more potent against $\mathrm{PI} 4 \mathrm{KIl} \alpha$ than $\mathrm{PI} 4 \mathrm{KII} \beta_{-}^{[19]}$ This compound is capable of differentiating the two isoforms and is likely to become an important experimental tool.

\subsection{PI4KII activity is tuned by membrane environment}

Evidence that PI4KIl $\alpha$ activity is regulated comes from the finding that membranes containing low and high activity pools of the enzyme can be separated by subcellular fractionation. ${ }_{-}^{[20]}$ It is clear from the three-dimensional structures that membrane interaction determines PI4KII activity, and that this is achieved through stable multiple S-palmitoylation ${ }_{\underline{-}}^{[21]}$ This modification tightly anchors PI4KIl $\alpha$ in membranes, such that only detergent treatment can release the protein ${ }_{-}^{[12]}$ Close membrane interaction renders PI4KII $\alpha$ activity exquisitely sensitive to its membrane environment ${ }_{2}{ }^{[22]}$ being activated by cholesterol ${ }^{[17]}$ and 
phosphatidylcholine, but inhibited by acidic lipids such as phosphatidic acid. ${ }_{\Sigma}^{[23]}$ The nature of this interaction is essential to understand how PI4KIl $\alpha$ activity responds to a changing environment, in particular the supply of PI substrate. Thus the molecular structures support numerous observations that PI4KIl $\alpha$ is regulated largely by intrinsic membrane factors.

PI4KII $\alpha$ activity is responsible for a large proportion of total PI4K activity in cell extracts but, in contrast, PI4KII $\beta$ activity is difficult to measure. ${ }_{-}^{[24]}$ Unlike PI4KII $\alpha$, a substantial proportion of $\mathrm{PI} 4 \mathrm{KII} \beta$ is extractable without the need for detergent ${ }^{[25]}$ indicating that it is only partially membrane associated, and it is likely that this difference is key to the regulation of PI4KII $\beta$ activity. Unlike PI4KIl $\alpha$, the $\mathrm{PI} 4 \mathrm{KII} \beta$ isoform is dynamically palmitoylated on cysteine residues within the conserved ${ }_{170} \mathrm{CCPCC}_{174}$ motif (Figure $1 \mathrm{~A}$ ). Membrane recruitment of PI4KII $\beta$ is regulated and occurs in response to growth factors and on expression of constitutively active Rac1. ${ }_{\underline{.}}^{[26]}$

PI4KII $\beta$ binds the molecular chaperone HSP90 through a site in the Cterminal lobe, a region that is occluded in the tightly membrane bound PI4KIl $\alpha$. This interaction stabilises cytosolic PI4KII $\beta$ and prevents palmitoylation, and therefore membrane recruitment. Inhibition of the interaction releases PI4KII $\beta$ leading to degradation in the proteosome (Figure 3B). However, acute inhibition of the interaction leads to rapid palmitoylation and translocation to TGN and plasma membranes. This interaction is likely to be regulated by external stimuli because treatment with EGF or PDGF is sufficient to disrupt the HSP90-PI4KII $\beta$ complex ${ }_{-}^{[27]}$ Thus, it appears that both protein turnover and membrane translocation, and therefore substrate access, are under tight control. This indicates the existence of elaborate mechanisms controlling PI4KII $\beta$ activity, and suggests that this isoform is subject to stringent regulation in a manner quite distinct from PI4KIl $\alpha$.

\subsection{The lipid products of PI4KIls can be studied at the subcellular level}

Spatially distinct pools of PIs can be imaged at subcellular resolution by using recombinant probes that are now widely used in microscopy. ${ }^{[28]}$ The use of these has confirmed the existence of Ptdlns4P in the PM and, surprisingly, in multiple endosomal compartments $\left({ }^{[8,10,29]}\right.$, Figure 2$)$. 
Ptdlns4P levels on intracellular membranes are determined by the localisation and activity of the resident PI4Ks, but a central problem in the study of PI4KII function is that the Ptdlns4P produced is indistinguishable from the enzymatic products of other PI4K isoforms. Two other issues further complicate Ptdlns4P experiments: remarkably, some Ptdlns4P pools can supply lipid to adjacent membranes through non-vesicular traffic ${ }_{2}^{[30]}$ making it technically difficult to assign a membrane compartment to an individual isoform; also, dynamic changes in Ptdlns4P levels may not be detectable, for example, when Ptdlns4P is rapidly converted to another $\mathrm{PI}$. These cautions notwithstanding, cellular imaging and the manipulation of PIs has proved decisive in understanding PI4KII function.

The biosynthesis of Ptdlns $4 P$ by different PI4K isoforms can occur in metabolically separate pools ${ }_{-}^{[10,11]}$ Connecting each of these pools to a particular PI4KII activity in the absence of effective inhibitors has been challenging; however, the Balla laboratory has adopted and developed techniques to acutely manipulate PIs in different organelles by the inducible targeting of PI phosphatases: ${ }_{-}^{[31]}$ Thanks to this approach, which has since been used by several investigators, we know that Ptdlns $4 P$ is produced in the PM by PI4KIII $\alpha^{[8]}$ (as was predicted by many earlier studies $\left.^{[10]}\right)$, that Ptdlns $4 P$ can regulate a $P M$ calcium channel ${ }^{[32]}{ }_{2}$ that Ptdlns $4 P$ is present in LE and lysosomal membranes ${ }^{[8]}$ and that Ptdlns $4 P$ metabolism occurs during phagosomal maturation. ${ }_{\underline{-}}^{[33]}$

\section{PI4KIls have multiple roles in membrane trafficking}

Early studies indicated that the PI4KIIs localise to, and traffic between, the Golgi complex and endosomes ${ }^{[20,24,34]}$. It is now clear that most trafficking pathways involving PI4KIls can be traced back to the TGN; however, to understand the multitude of PI4KII pathways, it is important to recognise the complexity of communication between the TGN and endosomal compartments, which are highly heterogeneous and ultimately traffic cargo to the lysosome or $\mathrm{PM}_{-}{ }^{[35]}$ The TGN is itself a highly dynamic, PtdIns4P-rich compartment at the trans face of the Golgi apparatus that functions as an exit point where cargo is sorted into biosynthetic and endosomal pathways. The TGN also receives backward (retrograde) traffic from endosomal compartments ${ }_{-}^{[36]}$ The TGN therefore, plays critical functions as a sorting hub that coordinates many aspects of intracellular traffic, including secretion and the biogenesis of lysosomes and related organelles. PI4KIl $\alpha, \mathrm{PI} 4 \mathrm{KII} \beta$ 
and the Ptdlns4P the enzymes produce, all function at the TGN and associated membranes, and the following sections describe how the PI4KIls function in these processes.

\subsection{How the PI4KIls control traffic.}

Ptdlns4P is a factor in the recruitment of several clathrin adaptors at the TGN and therefore in determining the sorting of proteins into distinct pathways. For example, EpsinR is a Ptdlns4P-binding protein that mediates TGN-to-endosome cargo sorting $_{2}{ }^{[37]}$ as are the Golgi-localised $\gamma$-ear-containing Arf binding proteins (GGAs) ${ }_{2}^{[38]}$ which require Ptdlns4P synthesised by PI4KIl $\alpha$ for correct localisation ${ }_{-}^{[39]} \mathrm{PI} 4 \mathrm{KIl} \alpha$ is a significant Ptdlns4P biosynthetic activity at the TGN and it was originally reported that depletion of the enzyme delocalises the clathrin adaptor and Ptdlns4P effector AP- $1_{2}{ }^{[40]}$ which principally directs TGN-to-endosomal traffic. However, subsequent studies have failed to demonstrate colocalisation or direct interaction between PI4KII $\alpha$ and AP- ${ }_{\underline{-}}^{[9,41,42]}$ Instead PI4KIl $\alpha$ forms a direct complex with another adaptor, AP-3, via its dileucine interaction motif ${ }^{56} \mathrm{ERQPLL}^{61[42]}$ (Figure 1A). AP-3 controls traffic from EE/SE into the endolysosomal pathway. ${ }_{-}^{[43]}$ The finding that PI4KIl $\alpha$ is a component of AP-3 containing vesicles, along with many AP-3 cargoes $_{2}^{[44]}$ further supports the involvement of PI4KIl $\alpha$ in EE/SE-to-LE traffic (Figure 3A).

$\mathrm{PI} 4 \mathrm{KII} \beta$ is also found in the TGN where it colocalises with AP-1, and to a lesser degree with EE and LE markers, indicating that PI4KII $\beta$ is distributed between the TGN and endosomal systems. PI4KII $\beta$ contains the $N$-terminal dileucine sequence ${ }^{25} \mathrm{EREPLL}^{30}$ that specifically binds $A P-1$, rather than $A P-3_{-}^{[45]}$ This AP-1 complex is required to localise PI4KII $\beta$ to the TGN and PI4KII $\beta$ knockdown causes mislocalisation of AP-1, indicating that the proteins are functionally interdependent. Importantly, by virtue of their adaptor recognition motifs, both PI4KII isoforms are effectively cargoes that promote the recruitment of their cognate adaptors. In the case of PI4KII $\beta / A P-1$, this depends on the biosynthetic activity of PI4KII $\beta$; whereas, with PI4KII $\alpha / A P-3$, despite having a requirement for both kinase activity and an intact dileucine motif, evidence supporting a direct role for Ptdlns4P in AP-3 recruitment has been elusive. However, the PI4KII isoforms synthesise spatially separate pools of Ptdlns4P in 
the TGN-endosomal system ${ }^{[11]}$ (Figure 2) and a pool of Ptdlns4P is required for AP-3 cargo trafficking ${ }_{2}{ }^{[46,47]}$ arguing that both PI4K-adaptor systems are dependent on Ptdlns4P. In summary, it is clear that PI4KII isoforms operate in different postTGN trafficking pathways by utilising distinct PI4KII-dependent clathrin adaptor systems, and that the PI4KII $\alpha / A P-3$ and PI4KII $/$ AP-1 complexes exhibit a similar reciprocal relationship between location and function.

\subsection{Late endosomal traffic: degradation or recycling?}

The epidermal growth factor receptor (EGFR) is a potent tyrosine kinase and significant human oncogene that, when activated, is rapidly downregulated by traffic to late endosomes (LEs). PI4KIl $\alpha$ is necessary for efficient EGFR trafficking and degradation ${ }_{2}^{[34]}$ and whilst $\mathrm{PI} 4 \mathrm{KII} \alpha$ may play a role in trafficking the receptor into the LE pathway, the traffic of hydrolytic enzymes to the lysosome may also contribute indirectly to impaired degradation in siRNA-treated cells. ${ }_{-}^{[47]}$ Furthermore, EGFR degradation is likely to be influenced by interaction of PI4KIl $\alpha$ with the ubitquitin proteosome system. PI4KIl $\alpha$ directly binds to the E3 ubiquitin ligase Itch at the TGN-endosome boundary, an interaction that increases Itch ubiquitin ligase activity whilst decreasing PI4KII $\alpha$ activity. This interaction has important functional consequences for canonical Wnt signalling because the formation of the complex has the effect of facilitating the sorting of frizzled receptors for degradation, thereby determining the output of this major developmental signalling pathway ${ }_{-}^{[41]}$

After they exit the TGN, newly synthesised soluble hydrolases rely on mannose-6-phosphate receptors (M6PR) for delivery to lysosomes ${ }_{-}^{[48]}$ Depletion of either PI4KII $\alpha$ or PI4KII $\beta$ affects traffic of the cation-independent M6PR, which is an AP-1 cargo sorted to the LE through an AP-3 pathway, and it is likely that Ptdlns4P generated by the PI4KII isoforms is responsible for this ${ }_{-}^{[40,45]} \mathrm{PI} 4 \mathrm{KII} \alpha$ is required for co-trafficking of the lysosomal hydrolase $\beta$-glucocerebrosidase (GBA) and its receptor, the AP-3 cargo LIMP-2. GBA is essential for the metabolism of lysosomal glucosylceramide and mutations in GBA that affect binding to LIMP-2 lead to missorting and lysosomal accumulation of glucosylceramide. Interestingly, although PI4KIl $\alpha$ binds AP-3, and is clearly active in SE membranes, kinase dead PI4KIl $\alpha$ is able to partially rescue AP-3 trafficking defects ${ }_{-}^{[42,47]}$ It is currently 
unclear why this phenomenon occurs but it is possible that an alternative activity is responsible for generating Ptdlns4P at this locus.

Phagocytic cells use endosomal trafficking to deliver internalised pathogens and cell debris to the lysosome. As with endolysosomal traffic, phagosomes undergo maturation through early and late compartments, finally fusing with lysosomes. Two phases of Ptdlns4P synthesis occur on maturing phagosomes: initially a transient phase, probably the result of PI4KIIl $\alpha$ activity, followed by a sustained phase that precedes lysosomal fusion that corresponds to the late stage of phagocytosis. Mature phagocytic membranes contain PI4KIl $\alpha$, which synthesises Ptdlns4P during this phase of maturation ${ }_{-}^{[33,49]}$ This Ptdlns4P pool presumably mediates traffic and fusion with lysosomes, probably by recruitment of the Rab7 effector RILP. An analogous heterotypic fusion process has been described involving the Atg8 family member $\gamma$-aminobutyric acid receptorassociated protein (GABARAP) that binds to and colocalises with PI4KIl $\alpha$ on autophagic structures, along with Ptdlns4P (Figure 2) ${ }_{-}^{[46,50]}$ siRNA of PI4KIl $\alpha$ or overexpression of the inactive kinase leads to the accumulation of enlarged autophagosomes, whose appearance can be phenocopied by GABARAP depletion. This phenotype can be rescued with exogenous Ptdlns $4 P$; $^{[50]}$ therefore, the formation of large autophagosomes may be due to preventing the local generation of Ptdlns $4 P$ and the impairment of autophagosome-lysosome fusion. The parallels between the processes of phagocytosis and autophagy are clear and it is likely that the role of PI4KIl $\alpha$ in heterotypic fusion is conserved.

\subsection{PI4KIls determine the fate of cargoes through TGN sorting and endosomal exit.}

PI4KIl $\alpha$ exists in varying amounts in the TGN, EE, LE, recycling compartments and at the PM (Figure 3A). Mechanistic information on the trafficking steps that determine this broad subcellular distribution is, however, scarce. We know that siRNA of PI4KIl $\alpha$ results in the mislocalisation of recycling ${ }^{[24]}$ and late endosomal cargoes, ${ }^{[34,44]}$ and impaired sorting of the epidermal growth factor receptor (EGFR) and transferrin to degradative and recycling fates, respectively ${ }_{-}^{[9]}$ It appears that, rather than dynamic recruitment of the enzyme, the constitutively membrane-bound PI4KII $\alpha$ is sorted, cargo-like, into different pathways through 
interaction with SNAREs. PI4KIl $\alpha$ binds to the R-snare VAMP3 on SEs where it facilitates retrograde delivery back to the TGN. Furthermore, the close homolog VAMP7 was identified as a component of AP-3 and PI4KIl $\alpha$-containing vesicles, ${ }^{[42]}$ where it mediates fusion with the LE. Thus converging evidence supports a role for SNAREs and PI4KIl $\alpha$ in sorting into retrograde recycling and LE pathways, probably determining the balance of traffic between these diverging routes (Figure $3 A)$.

The association of PI4KII with membranes derived from secretory tissues is well documented and extracts of these have proved to be rich sources of activity ${ }_{-}^{[7}$ ${ }^{12]}$ Aside from the work describing PI4KII in the control of post-TGN and endosomal trafficking, there is also a substantial body of work supporting a role for PI4KIl $\alpha$ in traffic towards the PM (Table 2; Figure 3A). An explanation for this is provided by the fact that endosomal compartments can serve as intermediates in trafficking to the plasma membrane, particularly in specialised secretory cells ${ }_{-}^{[51]}$ Such a pathway has been described originating at EE/SEs (Figure $3 \mathrm{~A}$ ) that involves the Ptdlns3P-phosphatase myotubularin 1 (MTM1) ${ }_{-}^{[52]}$ Hydrolysis of endosomal Ptdlns $3 P$ is required during the exocytotic step returning the unloaded TfR to the plasma membrane. Failure to hydrolyse Ptdlns $3 P$ results in impaired exit from endosomes, and consequently, the accumulation of exocytic cargoes. Normally, MTM1 is recruited to Ptdlns3P-containing EE/SEs that also harbour PI4KII $\alpha^{[24,34,}$ ${ }^{53]}$ and when Ptdlns $3 P$ is hydrolysed, the Ptdlns produced becomes a substrate for resident PI4KII $\square \square \square$ In the context of a membrane in which the supply of Ptdlns may be limited, and where the local environment is optimal for kinase activity, then the result would be increased local Ptdlns $4 P$ synthesis, effectively converting Ptdlns $3 P$ on EE/SEs into Ptdlns4P. This is a significant switch in membrane identity because Ptdlns3P-positive endosomes are unable to fuse with the PM; however, vesicles containing Ptdlns4P, that arise from the closely connected RE, can (Figure 3A) ${ }_{-}^{[52]}$ Generation of Ptdlns4P also leads to recruitment of the exocyst complex, which interacts with PI4KIla. Exocyst mediates the docking and membrane insertion of exocytic and recycling cargoes such as TfR and integrin $\beta 1$; therefore, MTM1 and PI4KII $\alpha$ forms a conversion module controlling endosomal exocytosis by switching PI metabolism from Ptdlns3P to Ptdlns4P. It also shows that PI4KIl $\alpha$ is a more versatile enzyme that functions, not only in trafficking to the LE and terminal processes such as lysosomal fusion but also in anterograde traffic. 


\subsection{PI4KII-mediated traffic is linked to the actin cytoskeleton}

Numerous actin-binding proteins interact both with PIs and elements of endocytic machinery, thereby linking $\mathrm{PI}$ metabolism with actin dynamics in membrane trafficking processes. For example, actin polymerisation is required to propel newly endocytosed cargoes though the cytoplasm on comet-like structures ${ }_{2}^{[54]}$ and requirements for actin polymerisation have been identified in LE to lysosomal traffic and in recycling. The Wiskott-Aldrich syndrome (WAS) family of actin branching regulators are targets of Ptdlns $(4,5) P_{2}$ that are frequently implicated in endosomal trafficking pathways ${ }_{-}^{[55]}$ A clue that PI4KII enzymes may have a conserved role in actin-dependent endocytic traffic comes from the sole PI4KII homolog of the yeast S. cerevisiae, Lsb6, which is a binding protein of the yeast Wiskott-Aldrich syndrome protein (WASp) homolog Las $17_{\underbrace{[56]}}$

During phagocytosis and Listeria monocytogenes infection, movement through the cytoplasm is accompanied by the dynamic formation of actin-rich comets. These require the coordinated activities of actin nucleating machinery ARP2/3, Ena-VASP and WASp. Both PI4KII isoforms are recruited to internalised beads coated with the bacterial cell surface protein InIB and these pseudophagosomes become decorated with Ptdlns4P. ${ }^{[57]}$

PI4KII $\alpha$ exists in complex with a large number of actin regulatory proteins including RhoGEF1 and several subunits of the actin nucleation promoting WASH complex $_{2}^{[41,53]}$ which, together with Arp2/3, regulates endosome morphology and trafficking. ${ }_{-}^{[58]} \mathrm{PI} 4 \mathrm{KIl} \alpha$ also colocalises with fluorescent actin on EEs that contain branched actin. The close association of PI4KIl $\alpha$ with actin regulatory machinery and the necessity for Ptdlns4P synthesis on endosomes together suggests that PI4KIl $\alpha$ participates in the synthesis of an EE pool of Ptdlns $(4,5) P_{2}$. In support of this, we recently demonstrated that Ptdlns $4 P$ and Ptdlns $(4,5) P_{2}$ exist in separate endosomal microdomains and that PI4KIl $\alpha$ is required for correct early endosomal sorting of the EGFR and Tf through the synthesis of Ptdins $4 P_{x^{[9]}}$

Ptdlns $(4,5) P_{2}$ levels in the EE are controlled by the Ptdlns $(4,5) P_{2} 5$ phosphatase OCRL, depletion of which leads to an N-WASp-dependent increase in endosomal F-actin and consequently the mistrafficking of TfR, EGFR and M6PR ${ }^{[59]}$ Ectopic accumulation of Ptdlns $4 P$ and Ptdlns $(4,5) P_{2}$ is also observed when Ptdlns4P hydrolysis by the Ptdlns4P phosphatase Sac1 is inhibited at 
endosome-ER contacts, resulting in aberrant trafficking of retrograde cargoes ${ }^{[60]}$. Interestingly, the activity of OCRL is also required on SEs to maintain correct traffic of multiple endosomal cargoes ${ }_{-}^{[59]}$ Together this evidence demonstrates the importance of regulating the levels of endosomal Ptdlns $4 P$ and Ptdlns $(4,5) P_{2}$ and, as the principal sources of early endosomal Ptdlns4P, the PI4KIIs are likely to assume greater importance at this site in the future.

\section{PI4KIls modulate Wnt signalling}

Wnt ligands control major developmental signalling cascades that are frequently dysregulated in human cancers ${ }_{-}^{[61]}$ Both PI4KII $\alpha$ and type I $\beta$ phosphatidylinositol 4phosphate 5-kinase (PIP5KI $\beta$ ) bind to, and are activated by, the Wnt scaffolding protein Dvl in a multiprotein complex synthesising PtdIns $(4,5) P_{2:}{ }^{\left[{ }^{[62]}\right.}$ Knockdown of PI4KIl $\alpha$ causes axis duplication in Xenopus $_{2}{ }^{[63]}$ a developmental defect linked to aberrant Wnt signalling. Another study showed that knockdown of PI4KIl $\alpha$ impaired the internalisation, endosomal traffic and degradation of the Wnt receptor frizzled $(\mathrm{Fz}){ }_{.}^{[41]}$ It is therefore likely that PI4KIl $\alpha$ is involved in at least two regulatory steps in canonical Wnt signalling: the formation of an activated signalling complex with Dvl promoting PM Ptdlns $(4,5) P_{2}$ synthesis at the PM and in a sorting complex that facilitates traffic to degradative compartments.

Knockdown of Zebrafish PI4KII $\beta$ affects Wnt target gene expression and causes developmental defects. In cell lines, the kinase exists in a complex with Dvl and axin1, both components of the canonical Wnt signalling cascade. Depletion of PI4KII $\beta$ leads to accumulation of endocytosed Fz in LEs, probably in transit for degradation. This accumulation can be rescued by ectopic expression of PI4KII $\beta$ but not with a mutant incapable of AP-1 binding, indicating that AP-1 dependent trafficking underlies the phenomenon. Consistent with this, the AP-1 complex is known to be important for traffic to basolateral domains of epithelial cells ${ }^{[64]}$ in developing embryos and interference with AP-1 perturbs the Wnt planar cell polarity (PCP) pathway ${ }^{[65]}$ important for organisation of embryonic tissues.

\section{PI4KII $\square$ are associated with cancer}


Both elevated and reduced levels of PI4KIl $\alpha$ expression are associated with cancers. For example, elevation has been detected in a diverse panel of human tumours and increasing PI4KIl $\alpha$ expression was observed during the development of tumours in a mouse xenograft model ${ }_{-}^{[66]}$ Meanwhile, ectopic overexpression of PI4KIl $\alpha$ but not a kinase dead mutant was sufficient to induce expression of HIF$1 \alpha$, an important factor allowing cells to survive the hypoxic tumour environment. The same group subsequently showed that PI4KIl $\alpha$ siRNA leads to degradation of Her2 and EGFR, and overexpression to Her2 activation ${ }_{-}^{[67]}$ Whilst the data supporting the hypothesis that PI4KIl $\alpha$ positively regulates EGFR levels and signalling is comprehensive and compelling, it is at odds with the established LE roles of PI4KIl $\alpha$ and in regulating the degradation of the EGFR ${ }^{[34]}$ and the fact that loss rather than gain of the PI4K2A gene is associated with an aggressive brain cancer ${ }_{-}^{[68]}$ However, PI4KIl $\alpha$ depletion studies have revealed complex effects on both the supply of Ptdlns $4 P$ for signalling and membrane trafficking. ${ }_{-}{ }^{69]}$ Thus it is likely that these discrepancies may reflect the inherent heterogeneity of tumours; nevertheless, it is clear that the dual targeting of EGFR family kinases and PI4KII $\alpha$ holds some promise as a personalised chemotherapeutic approach in certain cancers $^{[67]}$

PI4KII $\beta$ has been implicated in regulation of cell migration and metastasis of hepatocellular carcinoma through interaction with the tetraspanin $C D 81_{2}{ }^{[70]} \mathrm{a}$ molecule that has been shown previously to co-purify with PI4KII activity. ${ }^{[71]}$ siRNA of PI4KII $\beta$ leads to the formation of invasive structures, increased extracellular matrix degradation by the matrix type I metalloproteinase (MT1-MMP) and increased motility through collagen gels, thus indicating that PI4K2B has properties consistent with a suppressor of metastasis. In the same work, oncogenomic studies identified PI4KII $\beta$ loss as a risk factor in cancer ${ }_{\underline{-}}^{[11]}$

\subsection{PI4KIl $\alpha$ is linked to neurological disease}

Loss of PI4KIl $\alpha$ in mice leads to impaired neurological function resembling human spastic paraplegia, eventually resulting in premature death ${ }_{-}^{[72]}$ It is difficult to pinpoint a single trafficking step that may account for these defects given that PI4KIl $\alpha$ functions in LE, retrograde traffic and exocytosis but, in addition to axonal pathology, the mice show accumulation of lipofuscin-like deposits and membrane 
inclusions. This is consistent with deficient LE traffic or EE/SE exit to the Golgi ${ }^{[46,47]}$ (Figure 4) and such trafficking defects would explain the axonal degeneration and neuron loss in these mice.

Aberrant endolysosomal traffic is frequently associated with late onset neurodegenerative diseases ${ }_{-}^{[73]}$ As mentioned above, $\mathrm{PI} 4 \mathrm{KII} \alpha$ is responsible for the traffic of GBA from the TGN to endosomes where the complex is routed to lysosomes. Failure of this hydrolase to reach lysosomes results in failure to catabolise glucosylceramide and the accumulation causing Gaucher disease, the most common human lysosomal storage disease.

The ability PI4KIl $\alpha$ to bind AP-3 and recruit the clathrin adaptor to membranes has important implications for traffic to lysosomes and lysosomalrelated organelles. Hermansky-Pudlak syndrome is a rare autosomal recessive disease characterised by albinism and bleeding disorders. Like hereditary spastic paraplegia, Hermansky-Pudlak syndrome is genetically heterogeneous and can result from mutation in a number of loci encoding proteins involved in endolysosomal traffic. Clinical presentation and histopathology shows little in common with hereditary spastic paraplegia, but like the PI4KII $\alpha$ mouse knockout, lipofuscin deposition can be observed in some tissues. The adaptor complex AP-3 is just one gene affected in Hermansky-Pudlak syndrome, and PI4KIl $\alpha$ associates with multiprotein complexes known to be involved in Hermansky-Pudlak syndrome. ${ }_{-}^{[74]}$

Loss of function mutations of the MTM1 gene encoding a PI3-phosphatase leads to X-linked centronuclear myopathy (XLCNM), a severe congenital neuromuscular disease. As discussed previously, hydrolysis of endosomal Ptdlns $3 P$ and salvage of the Ptdlns formed by PI4KIl $\alpha$ appears to be a prerequisite for exocytic trafficking to the plasma membrane (Figure 4). Specific inhibitors for the PI 3-kinase hVPS34 have been developed and were shown to restore exocytic traffic to the $\mathrm{PM}_{2}{ }^{[52]}$ suggesting that they could form the basis for treatment of XLCNM.

Cholesterol, a membrane constituent and activator of PI4KIl $\alpha$, has long been implicated in the pathogenesis of Alzheimer's disease ${ }_{-}^{[75]}$ Steroid-like natural ginsenosides can reduce the accumulation of the amyloidogenic $A \beta \square \square \square \square \square \square \square$ in cultured neurons and the brains of an Alzheimer's mouse model, whilst enhancing the activity of PI4KIl $\alpha$ and increasing the levels of Ptdlns $4 P$ and Ptdlns $(4,5) P_{2}$ in 
cultured cells ${ }_{-}^{[76]}$ Cholesterol and sterol analogs are able to activate $\mathrm{PI} / 4 \mathrm{KII}_{2}{ }^{[17]}$ and although PI4KIl $\alpha$ has not been directly implicated in the pathology of Alzheimer's disease in recent gene studies, a plausible therapeutic strategy might be the upregulation $\mathrm{PI} 4 \mathrm{KIl} \alpha$ activity, or the inhibition of $\mathrm{PI}$ 4-phosphatases, to protect against the development of AD. However, testing this hypothesis would require exceptionally demanding longitudinal studies.

\section{Conclusions: Integrating PI4KII functions}

The discovery of Ptdlns4P on early and late endosomes, as well as the TGN, challenges the prevailing view that Ptdlns $3 P$ is an exclusive determinant of endosomal membrane identity. It is now clear that Ptdlns4P synthesis by PI4KII isoforms at these membranes performs decisive roles in cargo selection, sorting and in directing traffic. In early endosomes, Ptdlns $3 P$ can be converted to Ptdlns $4 P$ via dephosphorylation to the common Ptdlns precursor to accomplish endosomal exit and traffic toward the plasma membrane. A similar relationship between Ptdlns $3 P$ and Ptdlns $4 P$ has been noted during phagosomal maturation, suggesting that comparable conversion mechanisms exist in other trafficking pathways. Also, local Ptdlns4P synthesis by PI4KIIs can recruit different clathrin adaptors thereby controlling the traffic of different cargoes into distinct pathways and adding to the complexity of PI4KII trafficking.

Close membrane interaction as a result of palmitoylation is the principal determinant of PI4KII activity at membrane interfaces. Unlike all known PI kinases, which are invariably recruited to membranes containing their substrates, PI4KIl $\alpha$ is constitutively membrane associated. The emerging model then is one in which membrane-bound PI4KIl $\alpha$ is highly sensitive to its membrane environment, responding to activation with the local synthesis of Ptdlns4P. PI4KIl $\alpha$ activity can be further modulated in situ through the binding of proteins such as Itch that can regulate activity. Therefore, $\mathrm{PI} 4 \mathrm{~K}$ Il $\alpha$ appears to be a sensor capable of reacting to changes in membrane environment, such as cholesterol content and the local availability of Ptdlns, with increased synthesis of Ptdlns4P. In this way, PI4KIl $\alpha$ activity recruits Ptdlns $4 P$ effector proteins, alters membrane identity and redirects traffic from the EE/SE in specific directions such as toward the LE, Golgi or PM. The implication here is that membranes containing active PI4KII $\alpha$ could respond in a similar way to many other metabolic activities generating Ptdlns. 
Insight into the biology of $\mathrm{PI} 4 \mathrm{KII} \beta$ has lagged behind but it is clear that this isoform, in contrast to PI4KIl $\alpha$, can be regulated by extrinsic factors. Extracellular signals trigger membrane recruitment of the enzyme and therefore control its activity. The plasma membrane location of PI4KII $\beta$ is intriguing because it implies a function for Ptdlns4P synthesis at the PM, a role currently reserved for PI4KIIl $\alpha$. Also, it is not clear how PI4KII $\beta$ is specifically targeted to the plasma membrane by palmitoylation alone, and it is possible that additional factors are required. It is likely that PI4KII $\beta$ functions in developmental Wnt signalling at the plasma membrane, possibly by maintaining epithelial cell polarity and suppressing a migratory program. In support of this, loss of the enzyme is a risk factor in human cancers, which is also consistent with the notion that $\mathrm{PI} 4 \mathrm{KII} \beta$ is highly regulated under physiological conditions.

\section{Acknowledgements}

I am grateful to Prof Chang Chen (National Laboratory for Biomacromolecules, Institute of Biophysics, Chinese Academy of Sciences, Beijing) for Figure 1b. I thank Mark G. Waugh, Ganiyu Olabanji Alli-Balogun and Kar-Man Emily Chu for comments on the manuscript.

\section{Figure legends}

Table 1. Properties of the PI4KII isozymes. TGN, trans-Golgi network; EE, early endosome; SE, sorting endosome; LE, late endosome; Pg, phagosome; Lys, lysosome; Apg, autophagosome; EV, exocytic vesicle. *A large number of potential binding proteins have been identified by affinity purification and mass spectrometry, not all of which have been characterised in detail ${ }^{[41,44,45,53,74]}$.

\section{Table 2. PI4KIl $\alpha$ in anterograde traffic.}

Summary of evidence showing PI4KIl $\alpha$ in traffic towards the PM.

Figure 1. Structure of the PI4KII enzymes. A. The domain organisation of $\mathrm{PI} 4 \mathrm{KIl} \alpha$ and PI4KII $\beta$ is highly similar. The divergent $\mathrm{N}$-termini lack homology but contain interaction sites for clathrin adaptors. In PI4KII $\alpha$, a dileucine sorting motif ${ }^{57}$ERQPLL $^{62}$ is recognised by AP-3 ${ }^{[41,42]}$ whilst PI4KII $\beta$ contains a similar 
sequence $\left({ }^{25}\right.$ EREPLL $\left.{ }^{30}\right)$ that specifically binds AP-1 ${ }^{[45]}$. The N-ter of PI4KIl $\alpha$ also contains the sequence ${ }^{15} \mathrm{PPDY}^{18}$ that binds the WW3 domain of the ubiquitin ligase Itch $_{2}$ which mediates multi-ubiquitination of $\mathrm{PI}_{4} \mathrm{KII}^{[41]}$. The conserved catalytic core is now known to be composed of amino- $(\mathrm{N})$ and carboxy- $(\mathrm{C})$ terminal lobes. Both isoforms contain a conserved palmitoylation motif, ${ }^{174} \mathrm{CCPCC}^{178}$ in PI4KII $\alpha$ and PI4KII ${ }^{170} \mathrm{CCPCC}^{174}$. HSP90, which plays a role in the stability and membrane recruitment of $\mathrm{PI} 4 \mathrm{KII} \beta$, binds to a region between residues $315-481$ in the C-lobe ${ }^{[27]}$. This schematic is based on the human polypeptide sequences (NP_060895 and NP_060793.2). B. Model illustrating how the PI binding pocket of palmitoylated PI4KIl $\alpha$ interacts with membranes (adapted with permission ${ }^{[14]}$ ). Boxed area indicates palmitoylation loop.

\section{Figure 2. The subcellular distribution of Ptdlns4P}

Ptdlns $4 P$ is enriched in the Golgi complex where PI4KIII $\beta, P I 4 K I l \alpha$ and PI4KII $\beta$ are responsible for its synthesis. Imaging methods using recombinant proteins derived from Ptdlns $4 P$ binding domains have revealed pools at the plasma membrane (PM $\left.{ }^{[8]}\right)$, recycling endosome $\left(\mathrm{RE},{ }^{[52]}\right)$, early/sorting endosome (EE/SE, $\left.{ }^{[9,46]}\right)$, late endosome (LE, $\left.{ }^{[8]}\right)$, lysosome (Lys, ${ }^{[8]}$ ), autophagosome (Apg, ${ }^{[50]}$ ) and phagosome $\left(\mathrm{Pg},{ }^{[33,49]}\right.$. Discrete PI4K activities are responsible for this distribution and it is known that PI4KIII $\alpha$ is a major PtdIns4P biosynthetic activity at the PM (yellow). PI4KIII $\beta$ produces a pool in the Golgi apparatus (magenta), whereas PI4KIl $\alpha$ and PI4KII $\beta$ produce Ptdlns4P on separate domains of the TGN (red and green, respectively) ${ }^{[11]}$. PI4KIl $\alpha$ is also responsible for pools of Ptdlns4P on RE ${ }^{[52]}$, SE, LE and Apg membranes (blue) that are likely to be dynamically regulated. Furthermore, PI4KIl $\alpha$ generates PtdIns4P in late phagosomes.

TGN, trans-Golgi network; EE, early endosome; SE, sorting endosome; LE, late endosome; Pg phagosome; Lys, lysosome; Apg, autophagosome; EV, exocytic vesicle; RE, recycling endosome.

\section{Figure 3. The membrane trafficking functions of the type II PI 4-kinases.}

Both PI4KIl $\alpha$ and PI4KII $\beta$ localise to the TGN and endosomes, although it is likely that they exist in separate domains within the TGN-endosomal system. A. PI4KII $\alpha$ localises predominantly to the TGN and endolysosomal system but relatively minor pools have also been detected at the PM. At the early/sorting endosome (EE/SE), 
PI4KIl $\alpha$ recruits AP-3 to membranes participating in traffic to the LE; however, the enzyme is also involved in retrograde traffic via a VAMP3-dependent pathway. PI4KIl $\alpha$ further functions in degradative pathways by producing Ptdlns4P required for heterotypic fusion of lysosomal (Lys) and autophagosomal (Apg) membranes and an analogous process occurs in phagocytic cells ${ }^{[33,49]}$. PI4KIl $\alpha$ mediates exocytic traffic from endosomal compartments including the EE/SE via the recycling endosome (RE) ${ }^{[52]}$ and in a Rab27a-dependent step from the LE during HIV-1 viral assembly in T-cells ${ }^{[77]}$.

B. PI4KII $\beta$ is partially cytosolic and is dynamically palmitoylated in response to growth factors and expression of constitutively active Rac, which both lead to PM recruitment. PI4KII $\beta$ synthesises a pool of Ptdlns4P that colocalises with TGN46 (green; ${ }^{[11]}$ ). At the TGN, PI4KII $\beta$ is responsible for recruitment of the clathrin adaptor AP-1 ${ }^{[45]}$. The molecular chaperone HSP90 binds PI4KII $\beta$ preventing palmitoylation, thereby maintaining PI4KII $\beta$ in an inactive, cytosolic form whilst protecting the protein from proteosomal degradation ${ }^{[27]}$.

\section{Figure 4. PI4KII trafficking pathways of relevance to human disease.}

Five main pathways are affected by loss of PI4KII function in in vitro or whole animal models: TGN-to-endosomal traffic (i) is affected in zebrafish that have lost $\mathrm{PI} 4 \mathrm{KII} \beta$, resulting in developmental defects attributed to aberrant Wnt signalling ${ }^{[45]}$; (ii), loss of PI4KIl $\alpha$ impairs endosome-to-TGN traffic facilitated by VAMP3 ${ }^{[46]}$; endolysosomal traffic (iii) is affected by knockdown of $\mathrm{P} \mid 4 \mathrm{KII} \alpha_{2}$ which impairs degradation of lysosomal cargoes such as the EGFR ${ }^{[34]}$, the traffic of lysosomal membrane proteins ${ }^{[47]}$ and lysosome-related organelles ${ }^{[78]}$ and likely causes a phenotype in mice that is reminiscent of human spastic paraplegia (HSP; ${ }^{\text {[2] }}$. Note that this phenotype may reflect a defect in a lysosomal pathway or a retrograde step (i.e., ii); (iv) endosome-to-plasma membrane traffic controlled by PI4KIl $\alpha$ is affected by in human X-linked centronuclear myopathy (XLCNM) ${ }^{[52]}$; (v), LE-to-PM. PI4KIl $\alpha$ is trafficked from the LE to the PM in HIV infected T-cells ${ }^{[77]}$. Note that both PI4KIl $\alpha$ and PI4KII $\beta$ function in pathways that can culminate in traffic to the lysosome; therefore, knockdown of either isoform can give similar late endosomal/lysosomal phenotypes, leading some to conclude they have overlapping functions. 


\section{References}

[1] T. Balla, Physiol Rev 2013, 93, 1019.

[2] K. O. Schink, K. W. Tan, H. Stenmark, Annu Rev Cell Dev Biol 2016, 32, 143.

[3] M. A. De Matteis, C. Wilson, G. D'Angelo, Bioessays 2013, 35, 612.

[4] A. Balla, T. Balla, Trends Cell Biol 2006, 16, 351.

[5] S. Minogue, M. G. Waugh, Subcell Biochem 2012, 58, 1.

[6] M. Whitman, D. Kaplan, T. Roberts, L. Cantley, Biochem J 1987, 247, 165.

[7] E. S. Husebye, A. J. Letcher, D. J. Lander, T. Flatmark, Biochim Biophys Acta $1990,1042,330$.

[8] G. R. Hammond, M. P. Machner, T. Balla, J Cell Biol 2014, 205, 113.

[9] Y. Henmi, Y. Morikawa, N. Oe, N. Ikeda, A. Fujita, K. Takei, S. Minogue, K. Tanabe, Mol Biol Cell 2016, 27, 990.

[10] A. Balla, G. Tuymetova, A. Tsiomenko, P. Varnai, T. Balla, Mol Biol Cell 2005, 16, 1282.

[11] G. O. Alli-Balogun, C. A. Gewinner, R. Jacobs, J. Kriston-Vizi, M. G. Waugh, S. Minogue, Mol Biol Cell 2016, 27, 4033.

[12] B. Barylko, S. H. Gerber, D. D. Binns, N. Grichine, M. Khvotchev, T. C. Sudhof, J. P. Albanesi, J Biol Chem 2001, 276, 7705.

[13] S. Minogue, J. S. Anderson, M. G. Waugh, M. dos Santos, S. Corless, R. Cramer, J. J. Hsuan, J Biol Chem 2001, 276, 16635.

[14] Q. Zhou, J. Li, H. Yu, Y. Zhai, Z. Gao, Y. Liu, X. Pang, L. Zhang, K. Schulten, F. Sun, C. Chen, Nat Commun 2014, 5, 3552.

[15] A. Baumlova, D. Chalupska, B. Rozycki, M. Jovic, E. Wisniewski, M. Klima, A. Dubankova, D. P. Kloer, R. Nencka, T. Balla, E. Boura, EMBO reports 2014, 15, 1085.

[16] E. H. Walker, O. Perisic, C. Ried, L. Stephens, R. L. Williams, Nature 1999, 402, 313; V. D. Rao, S. Misra, I. V. Boronenkov, R. A. Anderson, J. H. Hurley, Cell 1998, 94, 829.

[17] M. G. Waugh, S. Minogue, D. Chotai, F. Berditchevski, J. J. Hsuan, J Biol Chem 2006, 281, 3757.

[18] M. Klima, A. Baumlova, D. Chalupska, H. Hrebabecky, M. Dejmek, R. Nencka, E. Boura, Acta Crystallogr D Biol Crystallogr 2015, 71, 1555.

[19] J. Li, Z. Gao, D. Zhao, L. Zhang, X. Qiao, Y. Zhao, H. Ding, P. Zhang, J. Lu, J. Liu, H. Jiang, C. Luo, C. Chen, Cancer Res 2017.

[20] M. G. Waugh, S. Minogue, J. S. Anderson, A. Balinger, D. Blumenkrantz, D. P. Calnan, R. Cramer, J. J. Hsuan, Biochem J 2003, 373, 57.

[21] D. Lu, H. Q. Sun, H. Wang, B. Barylko, Y. Fukata, M. Fukata, J. P. Albanesi, H. L. Yin, J Biol Chem 2012, 287, 21856.

[22] S. Minogue, K. M. Chu, E. J. Westover, D. F. Covey, J. J. Hsuan, M. G. Waugh, J Lipid Res 2010, 51, 2314; B. Mesmin, J. Bigay, J. Polidori, D. Jamecna, S. Lacas-Gervais, B. Antonny, EMBO J 2017.

[23] H. Olsson, W. Martinez-Arias, B. Jergil, FEBS Lett 1993, 327, 332.

[24] A. Balla, G. Tuymetova, M. Barshishat, M. Geiszt, T. Balla, J Biol Chem 2002, 277, 20041.

[25] G. Jung, J. Wang, P. Wlodarski, B. Barylko, D. D. Binns, H. Shu, H. L. Yin, J. P. Albanesi, Biochem J 2008, 409, 501.

[26] Y. J. Wei, H. Q. Sun, M. Yamamoto, P. Wlodarski, K. Kunii, M. Martinez, B. Barylko, J. P. Albanesi, H. L. Yin, J Biol Chem 2002, 277, 46586.

[27] G. Jung, B. Barylko, D. Lu, H. Shu, H. Yin, J. P. Albanesi, J Biol Chem 2011, 286, 12775. 
[28] O. Idevall-Hagren, P. De Camilli, Biochim Biophys Acta 2015, 1851, 736.

[29] G. R. Hammond, G. Schiavo, R. F. Irvine, Biochem J 2009, 422, 23.

[30] Z. Szentpetery, P. Varnai, T. Balla, Proceedings of the National Academy of Sciences of the United States of America 2010, 107, 8225.

[31] P. Varnai, B. Thyagarajan, T. Rohacs, T. Balla, J Cell Biol 2006, 175, 377.

[32] M. K. Korzeniowski, M. A. Popovic, Z. Szentpetery, P. Varnai, S. S. Stojilkovic, T. Balla, J Biol Chem 2009, 284, 21027.

[33] R. Levin, G. R. Hammond, T. Balla, P. De Camilli, G. D. Fairn, S. Grinstein, Mol Biol Cell 2017, 28, 128.

[34] S. Minogue, M. G. Waugh, M. A. De Matteis, D. J. Stephens, F. Berditchevski, J. J. Hsuan, Journal of cell science 2006, 119, 571.

[35] F. R. Maxfield, T. E. McGraw, Nat Rev Mol Cell Biol 2004, 5, 121.

[36] J. S. Bonifacino, R. Rojas, Nat Rev Mol Cell Biol 2006, 7, 568.

[37] I. G. Mills, G. J. Praefcke, Y. Vallis, B. J. Peter, L. E. Olesen, J. L. Gallop, P. J. Butler, P. R. Evans, H. T. McMahon, J Cell Biol 2003, 160, 213.

[38] J. S. Bonifacino, Nat Rev Mol Cell Biol 2004, 5, 23.

[39] J. Wang, H. Q. Sun, E. Macia, T. Kirchhausen, H. Watson, J. S. Bonifacino, H. L. Yin, Mol Biol Cell 2007, 18, 2646.

[40] Y. J. Wang, J. Wang, H. Q. Sun, M. Martinez, Y. X. Sun, E. Macia, T. Kirchhausen, J. P. Albanesi, M. G. Roth, H. L. Yin, Cell 2003, 114, 299.

[41] J. Mossinger, M. Wieffer, E. Krause, C. Freund, F. Gerth, M. Krauss, V. Haucke, EMBO reports 2012, 13, 1087.

[42] B. Craige, G. Salazar, V. Faundez, Mol Biol Cell 2008, 19, 1415.

[43] A. A. Peden, V. Oorschot, B. A. Hesser, C. D. Austin, R. H. Scheller, J. Klumperman, J Cell Biol 2004, 164, 1065.

[44] G. Salazar, B. Craige, B. H. Wainer, J. Guo, P. De Camilli, V. Faundez, Mol Biol Cell $2005,16,3692$.

[45] M. Wieffer, E. Cibrian Uhalte, Y. Posor, C. Otten, K. Branz, I. Schutz, J. Mossinger, P. Schu, S. Abdelilah-Seyfried, M. Krauss, V. Haucke, Curr Biol 2013, 23, 2185.

[46] M. Jovic, M. J. Kean, A. Dubankova, E. Boura, A. C. Gingras, J. A. Brill, T. Balla, Journal of cell science 2014, 127, 3745.

[47] M. Jovic, M. J. Kean, Z. Szentpetery, G. Polevoy, A. C. Gingras, J. A. Brill, T. Balla, Mol Biol Cell 2012, 23, 1533.

[48] S. Kornfeld, I. Mellman, Annu Rev Cell Biol 1989, 5, 483.

[49] A. Jeschke, N. Zehethofer, B. Lindner, J. Krupp, D. Schwudke, I. Haneburger, M. Jovic, J. M. Backer, T. Balla, H. Hilbi, A. Haas, Proceedings of the National Academy of Sciences of the United States of America 2015.

[50] H. Wang, H. Q. Sun, X. Zhu, L. Zhang, J. Albanesi, B. Levine, H. Yin, Proceedings of the National Academy of Sciences of the United States of America 2015, 112, 7015.

[51] A. L. Ang, T. Taguchi, S. Francis, H. Folsch, L. J. Murrells, M. Pypaert, G. Warren, I. Mellman, J Cell Biol 2004, 167, 531.

[52] K. Ketel, M. Krauss, A. S. Nicot, D. Puchkov, M. Wieffer, R. Muller, D. Subramanian, C. Schultz, J. Laporte, V. Haucke, Nature 2016, 529, 408.

[53] P. V. Ryder, R. Vistein, A. Gokhale, M. N. Seaman, M. A. Puthenveedu, V. Faundez, Mol Biol Cell 2013, 24, 2269.

[54] S. Benesch, S. Lommel, A. Steffen, T. E. Stradal, N. Scaplehorn, M. Way, J. Wehland, K. Rottner, J Biol Chem 2002, 277, 37771; J. Taunton, B. A. Rowning, M. L. Coughlin, M. Wu, R. T. Moon, T. J. Mitchison, C. A. Larabell, J Cell Biol 2000, 148, 519; A. L. Rozelle, L. M. Machesky, M. Yamamoto, M. H. Driessens, R. H. Insall, M. G. Roth, K. Luby-Phelps, G. Marriott, A. Hall, H. L. Yin, Curr Biol 2000, 10, 311.

[55] H. Miki, K. Miura, T. Takenawa, EMBO J 1996, 15, 5326. 
[56] F. S. Chang, G. S. Han, G. M. Carman, K. J. Blumer, J Cell Biol 2005, 171, 133.

[57] J. Pizarro-Cerda, B. Payrastre, Y. J. Wang, E. Veiga, H. L. Yin, P. Cossart, Cell Microbiol 2007, 9, 2381.

[58] S. N. Duleh, M. D. Welch, Cytoskeleton 2010, 67, 193.

[59] M. Vicinanza, A. Di Campli, E. Polishchuk, M. Santoro, G. Di Tullio, A. Godi, E. Levtchenko, M. G. De Leo, R. Polishchuk, L. Sandoval, M. P. Marzolo, M. A. De Matteis, EMBO J 2011, 30, 4970.

[60] R. Dong, Y. Saheki, S. Swarup, L. Lucast, J. W. Harper, P. De Camilli, Cell 2016, $166,408$.

[61] A. Klaus, W. Birchmeier, Nat Rev Cancer 2008, 8, 387.

[62] Y. Qin, L. Li, W. Pan, D. Wu, J Biol Chem 2009, 284, 22544.

[63] W. Pan, S. C. Choi, H. Wang, Y. Qin, L. Volpicelli-Daley, L. Swan, L. Lucast, C. Khoo, X. Zhang, L. Li, C. S. Abrams, S. Y. Sokol, D. Wu, Science 2008, 321, 1350.

[64] J. S. Bonifacino, J Cell Biol 2014, 204, 7.

[65] J. M. Carvajal-Gonzalez, S. Balmer, M. Mendoza, A. Dussert, G. Collu, A. C. Roman, U. Weber, B. Ciruna, M. Mlodzik, Nat Commun 2015, 6, 6751.

[66] J. Li, Y. Lu, J. Zhang, H. Kang, Z. Qin, C. Chen, Oncogene 2010, 29, 2550.

[67] J. Li, L. Zhang, Z. Gao, H. Kang, G. Rong, X. Zhang, C. Chen, Protein Cell 2014, 5,

457.

[68] M. G. Waugh, Mol Neurobiol 2016, 53, 621.

[69] K. M. Chu, S. Minogue, J. J. Hsuan, M. G. Waugh, Cell Death Dis 2010, 1, e106.

[70] A. Mazzocca, F. Liotta, V. Carloni, Gastroenterology 2008, 135, 244.

[71] F. Berditchevski, K. F. Tolias, K. Wong, C. L. Carpenter, M. E. Hemler, J Biol Chem 1997, 272, 2595.

[72] J. P. Simons, R. Al-Shawi, S. Minogue, M. G. Waugh, C. Wiedemann, S. Evangelou, A. Loesch, T. S. Sihra, R. King, T. T. Warner, J. J. Hsuan, Proceedings of the National Academy of Sciences of the United States of America 2009, 106, 11535.

[73] A. M. Schreij, E. A. Fon, P. S. McPherson, Cell Mol Life Sci 2016, 73, 1529.

[74] G. Salazar, S. Zlatic, B. Craige, A. A. Peden, J. Pohl, V. Faundez, J Biol Chem 2009, 284, 1790.

[75] G. Di Paolo, T. W. Kim, Nature reviews. Neuroscience 2011, 12, 284.

[76] M. S. Kang, S. H. Baek, Y. S. Chun, A. Z. Moore, N. Landman, D. Berman, H. O. Yang, M. Morishima-Kawashima, S. Osawa, S. Funamoto, Y. Ihara, G. Di Paolo, J. H. Park, S. Chung, T. W. Kim, J Biol Chem 2013, 288, 20868.

[77] P. P. Gerber, M. Cabrini, C. Jancic, L. Paoletti, C. Banchio, C. von Bilderling, L. Sigaut, L. I. Pietrasanta, G. Duette, E. O. Freed, S. Basile Gde, C. F. Moita, L. F. Moita, S. Amigorena, P. Benaroch, J. Geffner, M. Ostrowski, J Cell Biol 2015, 209, 435.

[78] M. Lopes da Silva, M. N. O'Connor, J. Kriston-Vizi, I. J. White, R. Al-Shawi, J. P. Simons, J. Mossinger, V. Haucke, D. F. Cutler, Journal of cell science 2016, 129, 2096.

[79] R. L. Del Vecchio, P. F. Pilch, J Biol Chem 1991, 266, 13278; S. Kristiansen, T. Ramlal, A. Klip, Biochem J 1998, 335 ( Pt 2), 351; Z. Xu, G. Huang, K. V. Kandror, Mol Endocrinol 2006, 20, 2890.

[80] Y. Ishihara, T. Furuno, M. Nakanishi, Inflamm Res 2006, 55, 465.

[81] C. Wiedemann, T. Schafer, M. M. Burger, EMBO J 1996, 15, 2094; J. Burgess, L. M. Del Bel, C. I. Ma, B. Barylko, G. Polevoy, J. Rollins, J. P. Albanesi, H. Kramer, J. A. Brill, Development 2012, 139, 3040.

[82] C. Panaretou, S. A. Tooze, Biochem J 2002, 363, 289. 


\begin{tabular}{|c|c|c|}
\hline \multirow[t]{2}{*}{ Table 1} & \multicolumn{2}{|c|}{ Properties of the PI4KII isozymes } \\
\hline & PI4KIl $\alpha$ & PI4KII $\beta$ \\
\hline $\begin{array}{l}\text { Subcellular } \\
\text { distribution }\end{array}$ & EE, LE, Pg, PM, Apg & TGN, EE, LE, cytosolic \\
\hline $\begin{array}{l}\text { Principal } \\
\text { functions }\end{array}$ & $\begin{array}{l}\text { EE and LE traffic, } \\
\text { Apg-Lys and Pg-Lys } \\
\text { fusion, exocytosis }\end{array}$ & TGN-endosomal traffic \\
\hline $\begin{array}{l}\text { Binding } \\
\text { proteins* }\end{array}$ & $\begin{array}{l}\text { AP-3 }{ }^{\text {(direct) }}, \text { BLOC-1, } \\
\text { exocyst } \\
\text { complex }^{\text {(unkown) }} \\
\text { Itch }^{\text {(direct) }} \\
\text { GABARAPs } \\
\text { (unknown) }\end{array}$ & HSP90 (direct), AP-1 (direct) $^{-1}$ \\
\hline $\begin{array}{l}\text { Membrane } \\
\text { association }\end{array}$ & $\begin{array}{l}\text { Constitutively } \\
\text { associated } \\
\text { (palmitoylation) }\end{array}$ & $\begin{array}{l}\text { Recruited in response to } \\
\text { growth factors (PM) }\end{array}$ \\
\hline $\begin{array}{l}\text { Upstream } \\
\text { regulators }\end{array}$ & Cholesterol, Itch (-ve) & $\begin{array}{l}\text { Rac, growth factors, HSP90, } \\
\text { Cholesterol (?) }\end{array}$ \\
\hline $\begin{array}{l}\text { Downstream } \\
\text { effectors }\end{array}$ & AP-3 & AP-1 \\
\hline
\end{tabular}




\begin{tabular}{|c|c|}
\hline PI4KIla fun & tions in anterograde traffic \\
\hline Trafficking process & References \\
\hline TGN>PM & {$[40]$} \\
\hline EE/SE>RE>PM & [52] \\
\hline LE>PM & {$[77]$} \\
\hline Glut4 >PM & [79] \\
\hline Mast cell degranulation & {$[80]$} \\
\hline Regulated secretion & [81] \\
\hline Secretory granule formation & {$[82]$} \\
\hline
\end{tabular}


Figure 1A. Minogue 2017
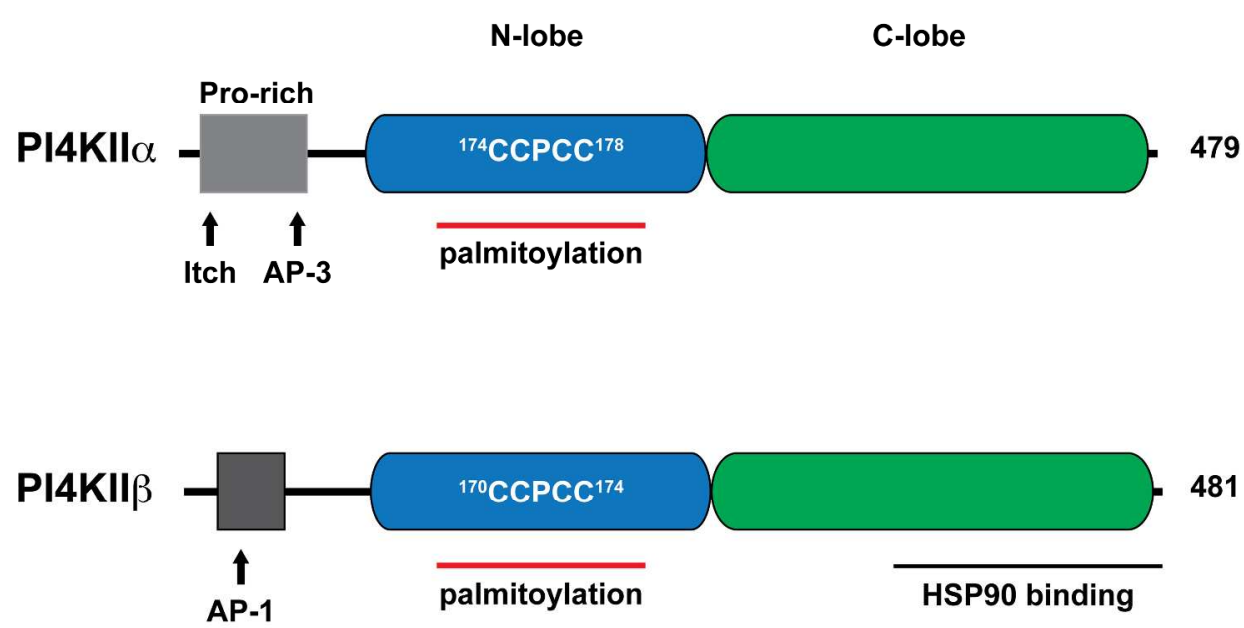

$243 \times 149 \mathrm{~mm}(300 \times 300$ DPI) 
Figure 1B. Minogue 2017

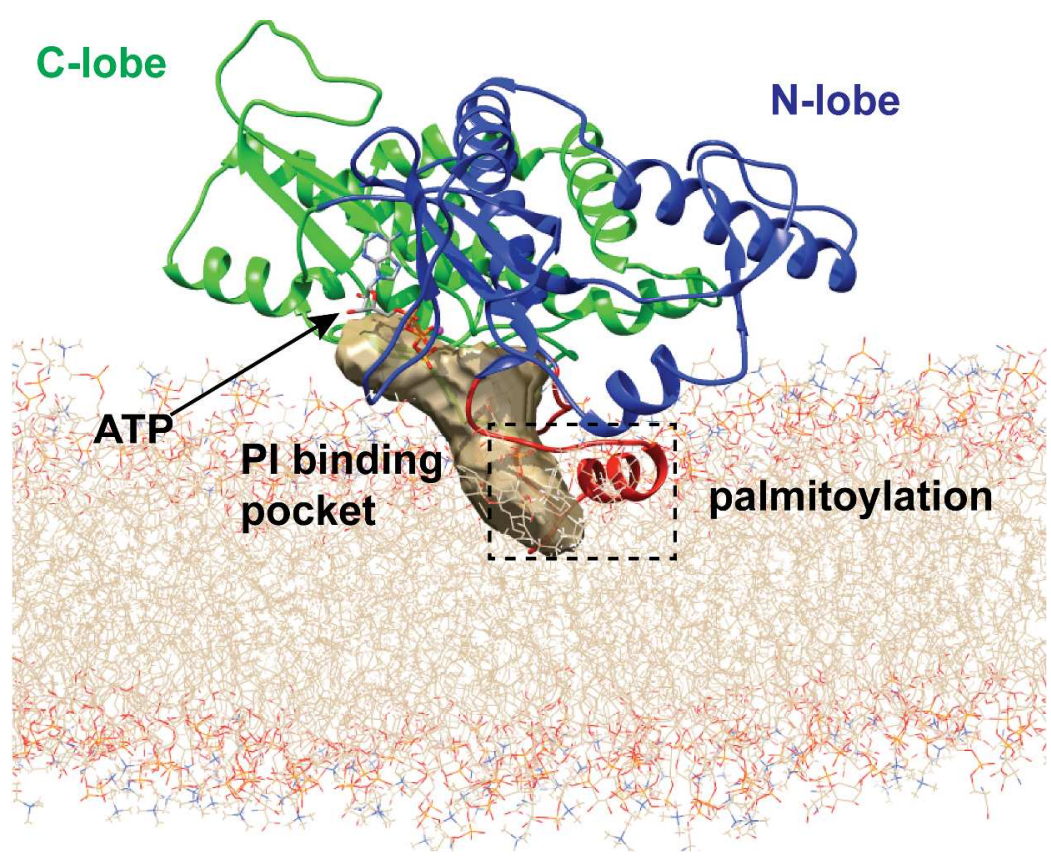

$293 \times 218 \mathrm{~mm}(300 \times 300$ DPI $)$ 
Figure 2 (Minogue 2017)

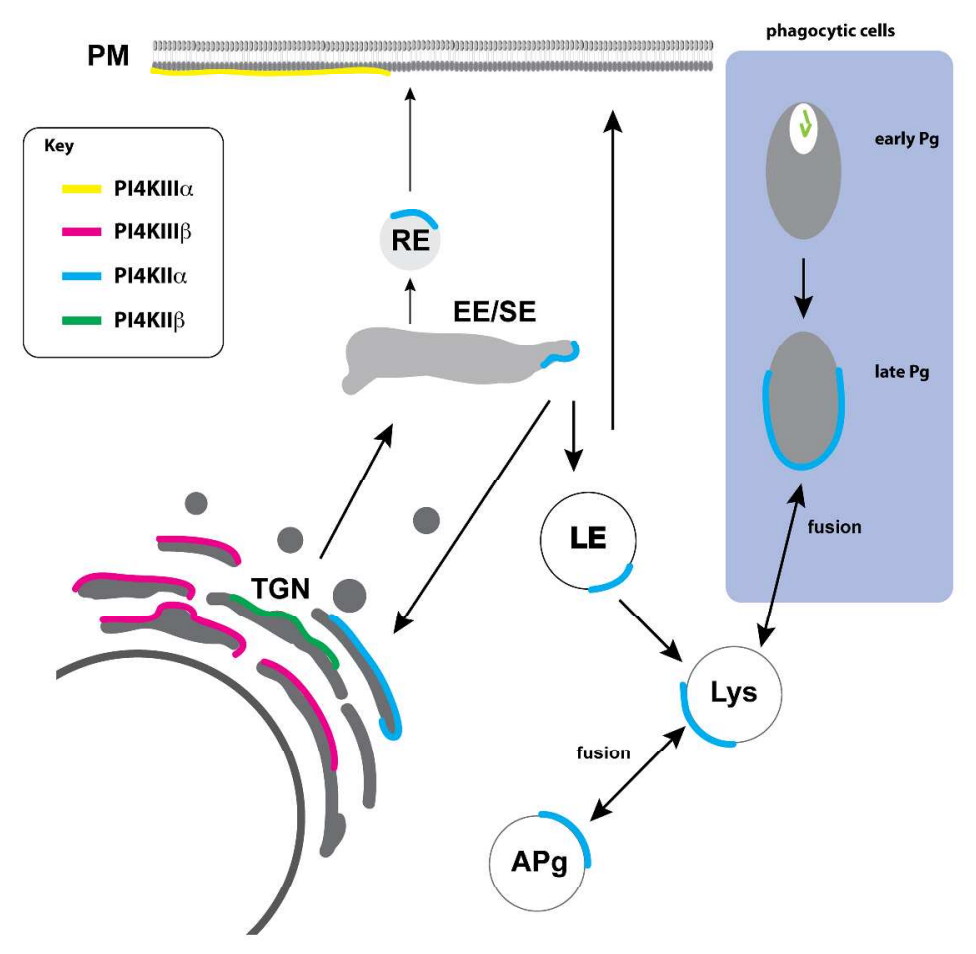

$353 \times 330 \mathrm{~mm}(300 \times 300$ DPI $)$ 


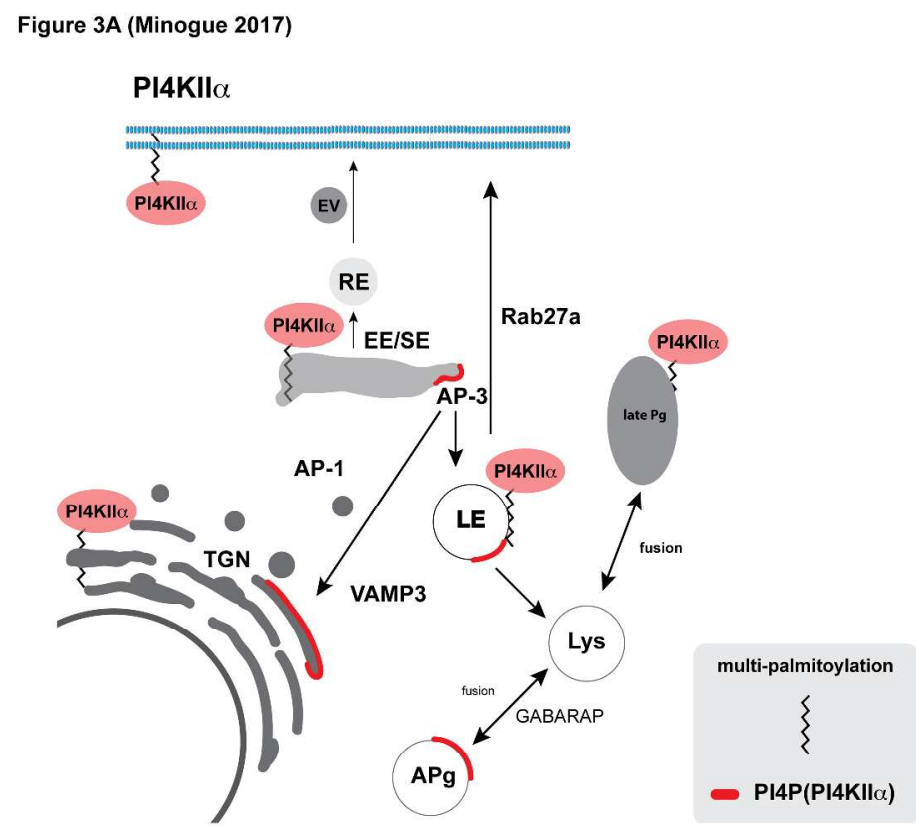

$446 \times 337 \mathrm{~mm}(300 \times 300$ DPI $)$ 


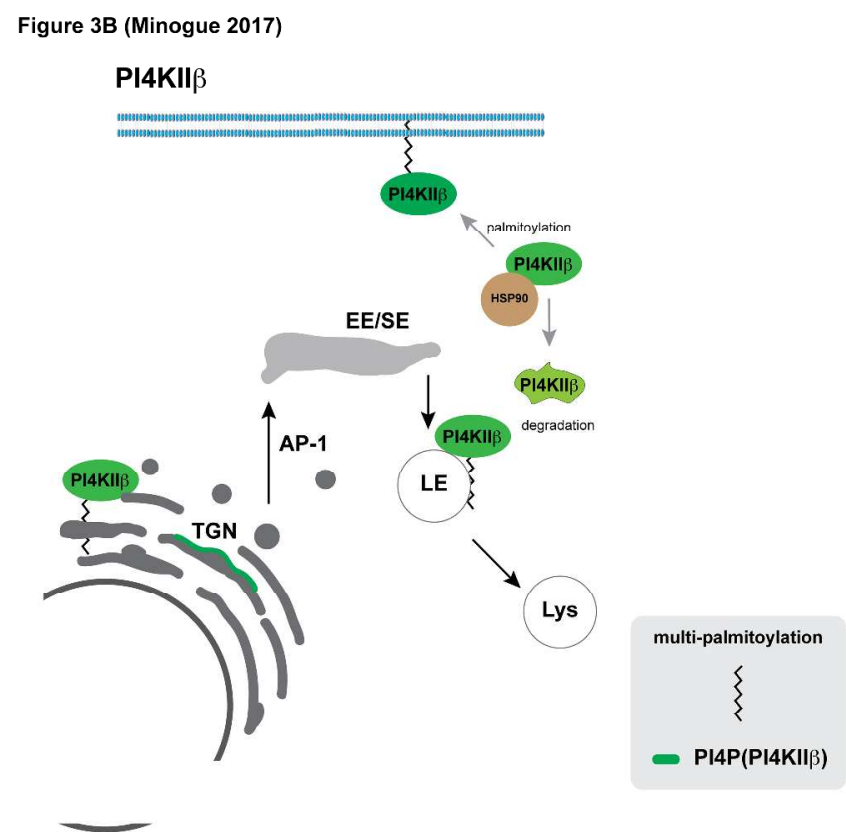

$464 \times 300 \mathrm{~mm}(300 \times 300$ DPI $)$ 
Figure 4 (Minogue 2017)

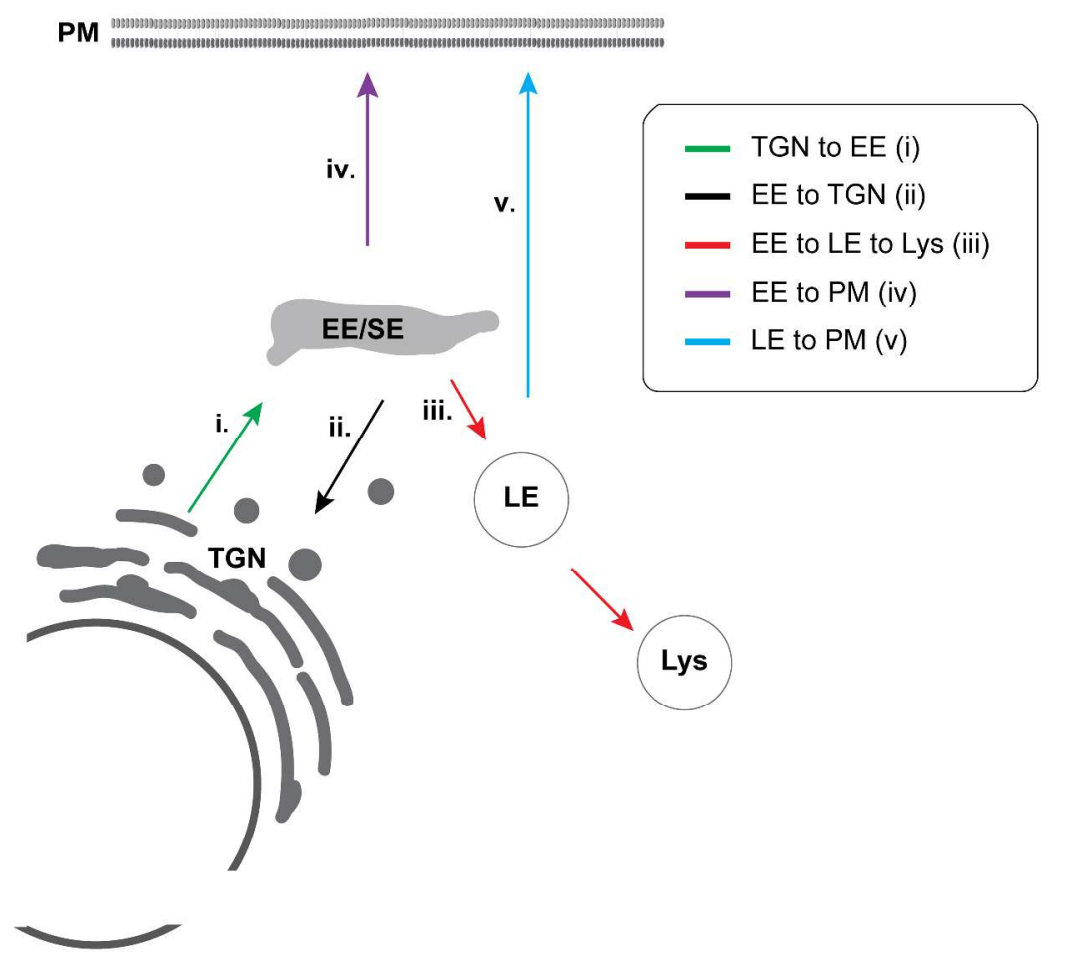

$358 \times 330 \mathrm{~mm}(300 \times 300$ DPI $)$ 


\section{Endolysosomal traffic Wnt signalling Autophagy \\ Cancer} Exocytosis
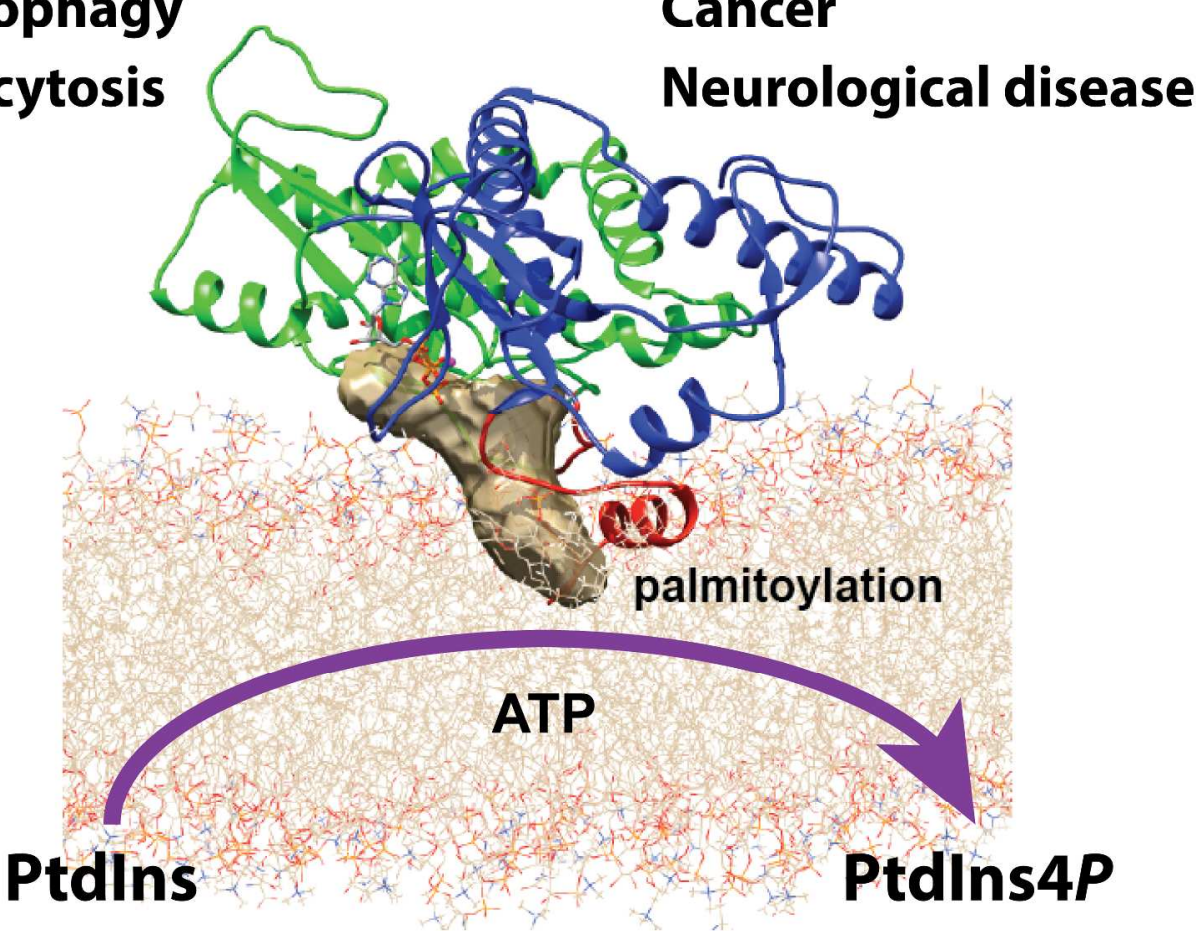

The type II phosphatidylinositol 4-kinases (PI4KIIs) are versatile mediators of membrane trafficking, controlling pathways that impact on disease. Recent advances suggest that the membrane lipid environment regulates enzyme activity and that the complexity of trafficking routes can be explained by the ability of these kinases to promote membrane trafficking in different directions. 